\title{
Web-Based Expert System for Diagnosing Gastric Disease Using Bayes Theorem Method
}

\section{Sistem Pakar Diagnosa Penyakit Lambung Menggunakan Metode Teorema Bayes Berbasis Web}

\author{
Ayu Anggilina ${ }^{1}$, Ade Eviyanti ${ }^{2}$ \\ \{ayuanggilina7@gmail.com¹, adeeviyanti@umsida.ac.id ${ }^{2}$ \}
}

Universitas Muhammadiyah Sidoarjo, Jl. Raya Gelam No. 250 Sidoarjo. 61271 Indonesia

\begin{abstract}
Health is a very expensive thing, so it takes an awareness to protect it. The human body has many limbs, one of which is the stomach. Gastric disease is a disease that cannot be accommodated, because if left untreated it can cause other diseases to arise and can also cause death if it is not immediately supported. Gastric disease can be caused by an inappropriate diet, a burden on the mind and also an infection caused by bacteria. The author took the initiative to create a web-based gastric disease diagnosis expert system using the Bayes theorem method which is useful for gastric disease sufferers in diagnosing their own gastric disease. The method used by researchers is the Bayes theorem method. The data collection technique used is quantitative data techniques. The results that have been achieved from this research are that it can prevent and minimize the risk of gastric disease in sufferers or the community.
\end{abstract}

Keywords - Lambung; Teorema Bayes; Expert System

Abstrak. Kesehatan merupakan suati hal yang sangat mahal maka, butuh sebuah kesadaran untuk menjaganya. Tubuh manusia terdiri dari banyak anggota tubuh salah satunya adalah lambung.penyakit lambung merupakan penyakit yang tidak bisa dianggap remeh, karena jika dibiarkan dapat mengakibatkan penyakit yang lain mencul dan bisa juga menyebabkan kematian jika tidak segera ditangani. Penyakit lambung dapat disebabkan oleh pola makan yang tidak sesuai, beban pikiran dan juga infeksi yang disebabkan oleh bakteri. penulis berinisiatif untuk membuat suatu sistem pakar diagnosa penyakit lambung berbasis web menggunakan metode teorema bayes yang berguna bagi penderita penyakit lambung dalam mendiagnosa penyakit lambung sendiri. Metode yang digunakan oleh peneliti adalah metode teorema bayes. Teknik pengumpulan data yang digunakan adalah teknik data kuantitatif. Hasil yang telah dicapai dari penelitian ini adalah dapat mencegah dan meminimalisir resiko penyakit lambung pada penderita atau masyarakat.

Kata Kunci - Lambung; Teorema Bayes; Sistem Pakar

\section{Pendahuluan}

Banyak orang yang kurang memperhatikan kesehatan itu sebabnya kesehatan merupakan hal yang sangat penting dan perlu dijaga. Salah satu contoh yaitu kesehatan lambung. Penyakit lambung timbul karena adanya infeksi oleh bakteri, beban pikiran, dan juga pola makanan yang kurang sehat [1]. Apabila dalam penanganannya tidak segera ditanggapi penyakit lambung menjadi hal yang sangat serius dan dapat menyebabkan penyakit lain muncul [2]. Salah satu contoh penyakit lambung adalah sakit maag (gastritis). Naiknya asam lambung yang berlebihan yang menyebabkan dinding lambung tidak kuat menahan asam lambung dan menimbulkan luka merupakan penyebab penyakit maag [3]. Jenis-jenis penyakit lambung diantaranya ialah maag (Gastritis), Dispepsia, Gastroephageal reflux disease (GERD) [4].

Berdasarkan penelitian yang telah dilakukan sebelumnya dengan tujuan sebagai alternatif untuk melakukan rujukan ke dokter [5], maka penulis berinisiatif untuk membuat suatu "Sistem Pakar Diagnosa Penyakit Lambung Berbasis Web Menggunakan Metode Teorema Bayes" yang bertujuan untuk memudahkan penderita penyakit lambung dalam melakukan diagnosa sejak dini serta mendaptkan solusi pengobatan yang tepat. Dengan adanya sistem pakar ini diharapkan mampu mempermudah proses diagnosa bagi penderita serta dapat menjadi rujukan selanjutnya ke dokter.

\section{METODE}

\section{A. Tahap pengumpulan data}

Pada penelitian ini, teknik pengumpulan data yang digunakan oleh peneliti diantaranya membaca buku dan jurnal yang terkait dengan topik penelitian yang diambil, kedua metode pengumpulan data dengan mengisi pertanyaan yang sudah dipersiapkan sebelumnya dan wawancara dengan pakar, ketiga observasi dengan cara mengamati langsung. 


\section{B. Subyek dan obyek penelitian}

Dalam penelitian ini subyek yang digunakan adalah pasien dari Rumah Sakit Rahman Rahim Sidoarjo dan masyarat umum, sedangkan obyek dari penelitian ini adalah seorang pakar atau dokter yang mengerti dan memahami dalam hal penyakit lambung.

\section{Teknik analisis masalah}

Masalah penyakit lambung pada seseorang merupakan kategori dari masalah Artificial Inteligent, atau bisa disebut dengan sistem pakar [6]. Maka, untuk memecahkan permasalahan tersebut diperlukan pengembangan sistem yang mampu sebagai peran seperti seorang ahli atau seorang pakar.

\section{Kerangka penelitian}

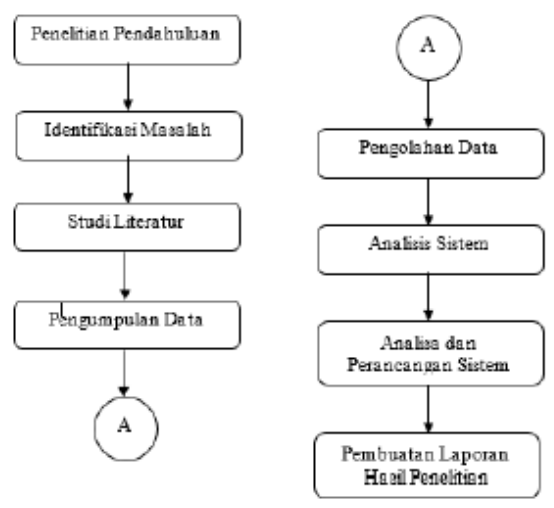

Gambar 1. Tahapan penelitian

Untuk menghasilkan penelitian yang baik dan sesuai dengan sasaran penelitian, maka dibuat sebuah alur penelitian yang sesuai dengan judul penelitian dan berisi langkah-langkah yang dilakukan dalam penelitian.

Tabel 1. Gejala Insomnia

\begin{tabular}{lll}
\hline No. & Kode tes & \multicolumn{1}{c}{ Gejala } \\
\hline 1. & G01 & Kesulitan menelan \\
2. & G02 & Suara serak \\
3. & G03 & Rongga mulut terasa asam \\
4. & G04 & Nyeri dada dan tenggorokan \\
5. & G05 & Mual dan muntah \\
6. & G06 & Cegukan \\
7. & G07 & Batuk kering \\
8. & G08 & Nyeri perut \\
9. & G09 & Gangguan pencernaan \\
10. & G10 & Nafsu makan berkurang \\
11. & G11 & Perut kembung \\
12. & G12 & Tinja bewarna hitam \\
13. & G13 & Berat badan menurun \\
14. & G14 & Pucat \\
15. & G15 & Perut kembung \\
16. & G16 & Nyeri ulu hati \\
17. & G17 & Mudah kenyang \\
18. & G18 & Sendawa \\
19. & G19 & Perut tidak nyaman \\
20. & G20 & Lemah \\
21. & G21 & Perut terasa penuh \\
22. & G22 & Tidak nafsu makan \\
23. & G23 & Perih di perut bagian atas \\
24. & G24 & Sering sendawa \\
25. & G25 & Nafsu makan berkurang \\
& &
\end{tabular}




\begin{tabular}{lll} 
26. & G26 & Keluar cairan dari lambung \\
27. & G27 & Naiknya asam lambung \\
28. & G28 & Cepat kenyang \\
29. & G29 & Fases berdarah \\
30. & G30 & Keringat dingin \\
\hline
\end{tabular}

Dari gejala yang dialami akan menghasilkan konklusi (kesimpulan akhir) atau bisa disebut juga dengan hasil identifikasi. Jenis penyakit lambung yang akan teridentifikasi pada penelitian ini ada 5 jenis yaitu Asam Lambung (Gerd), Gastritis, Tukak Lambung, Dispepsia (Maag), Kanker Lambung. Metode yang digunakan pada penelitian ini adalah metode teorema bayes [7].

Tabel 2. Identifikasi Insomnia

\begin{tabular}{lll}
\hline No. & Kode Penyakit & \multicolumn{1}{c}{ Nama Penyakit } \\
\hline 1. & P01 & Asam Lambung $($ Gerd) \\
2. & P02 & Gastritis \\
3. & P03 & Tukak Lambung \\
4. & P04 & Dispepsia (Maag) \\
5. & P05 & Kanker Lambung \\
\hline
\end{tabular}

Dari hasil identifikasi tabel 2, langkah selanjutnya adalah menentukan nilai probabilitas gejala penyakit seperti pada tabel 3 berikut ini :

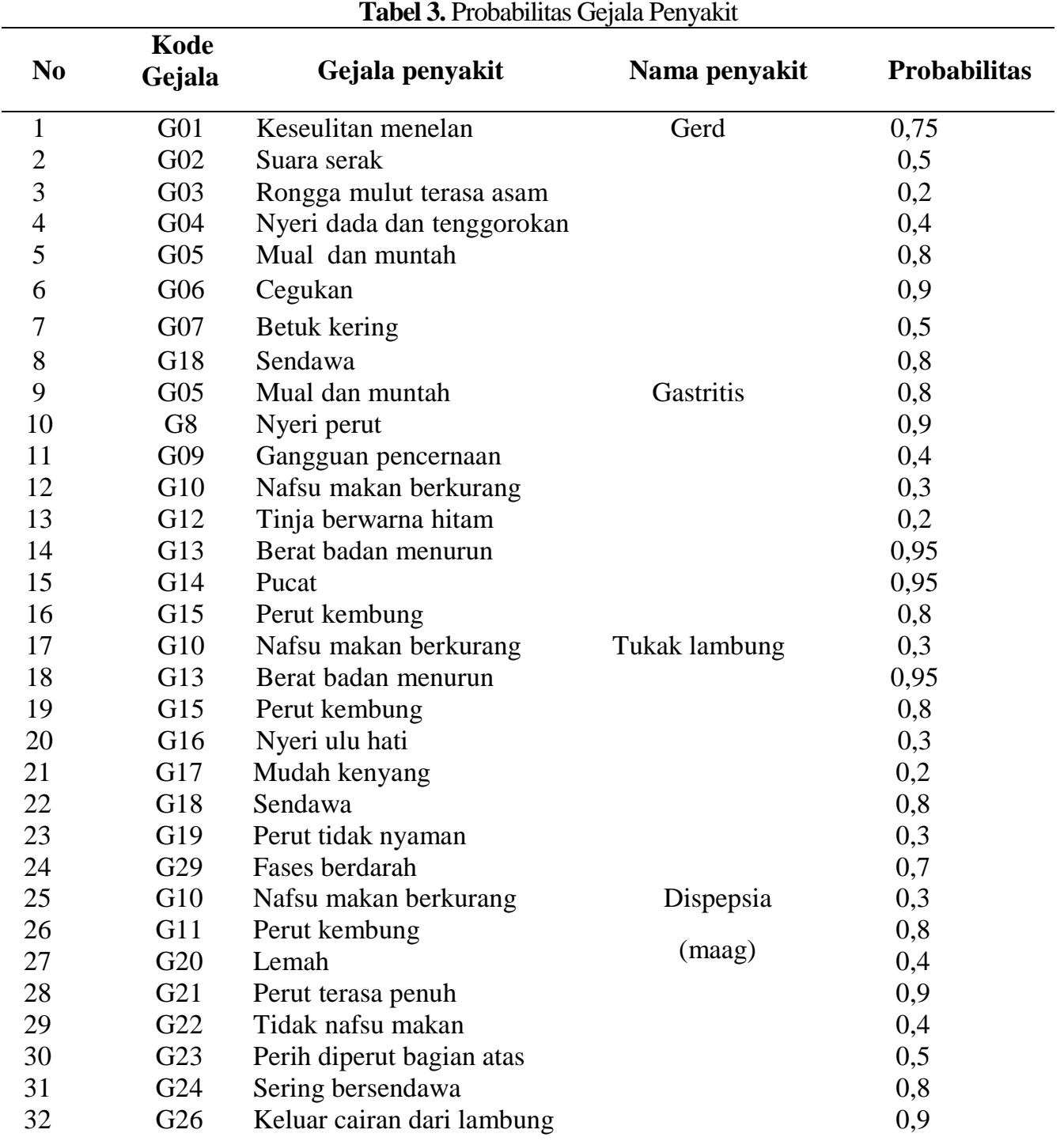


Procedia of Engineering and Life Science Vol. 1. No. 2 Juni 2021

Seminar Nasional \& Call Paper Fakultas Sains dan Teknologi (SENASAINS $2^{\text {nd }}$ )

Universitas Muhammadiyah Sidoarjo

\begin{tabular}{lllcc}
33 & G05 & Mual dan muntah & Kanker lambung & 0,8 \\
34 & G11 & Perut kembung & & 0,8 \\
35 & G16 & Nyeri ulu hati & & 0,3 \\
36 & G27 & Naiknya asam lambung & & 0,95 \\
37 & G28 & Cepat kenyang & & 0,7 \\
38 & G30 & Keringat dingin & & 0,3 \\
\hline
\end{tabular}

III. Hasil Dan Pembahasan

\section{A. Perancangan sistem}

Diagram konteks

Diagram konteks digunakan untuk menggambarkan keseluruhan rancangan sistem [8]. Berikut ini adalah rancangan diagram konteks dapat dilihat pada gambar 2. :

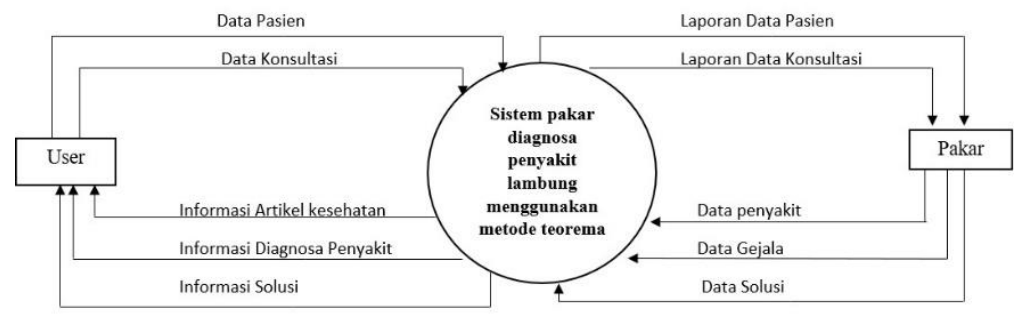

Data flow diagram (DFD)

Gambar 2. Diagram Konteks

Data Flow Diagram (DFD) digunakan sebagai alat untuk proses analisis kebutuhan perangkatilunak [9]. Adapun rancangannya adalah seperti pada gambar 3 berikut :

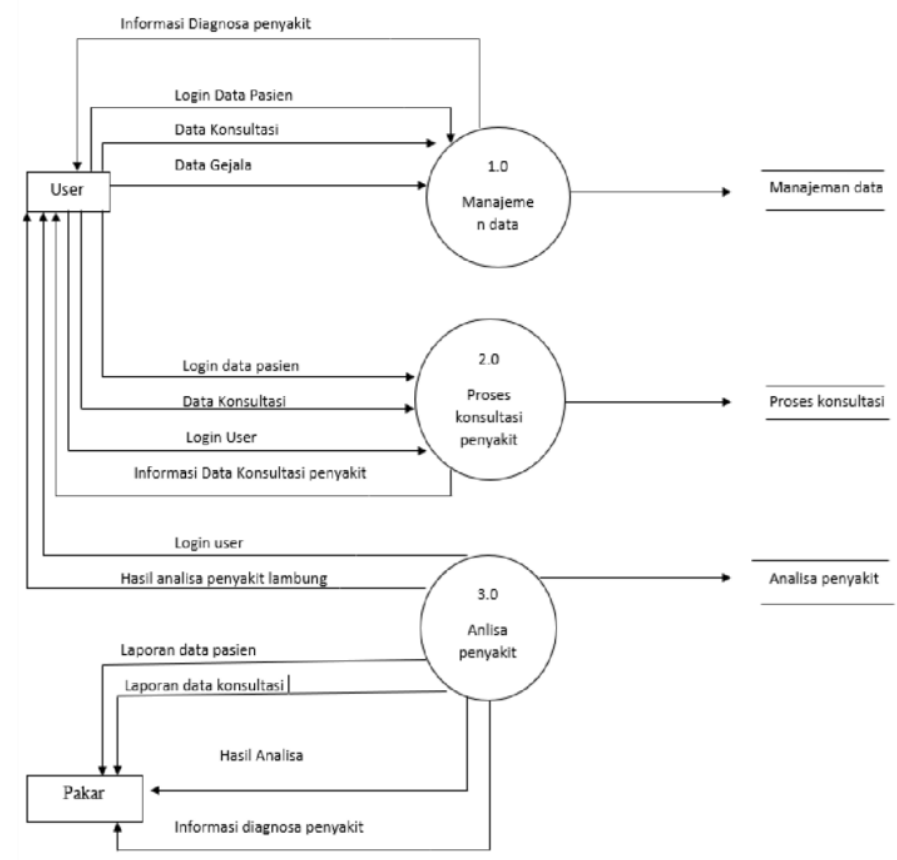

Entity relationship diagram (ERD)

Gambar 3. DFD

ERD adalah metode pemodelan basis data yang digunakan untuk menghasilkan skema konseptual untuk data yang sematik [10]. Berikut adalah rancangan ERD : 


\section{B. Desain user interface}

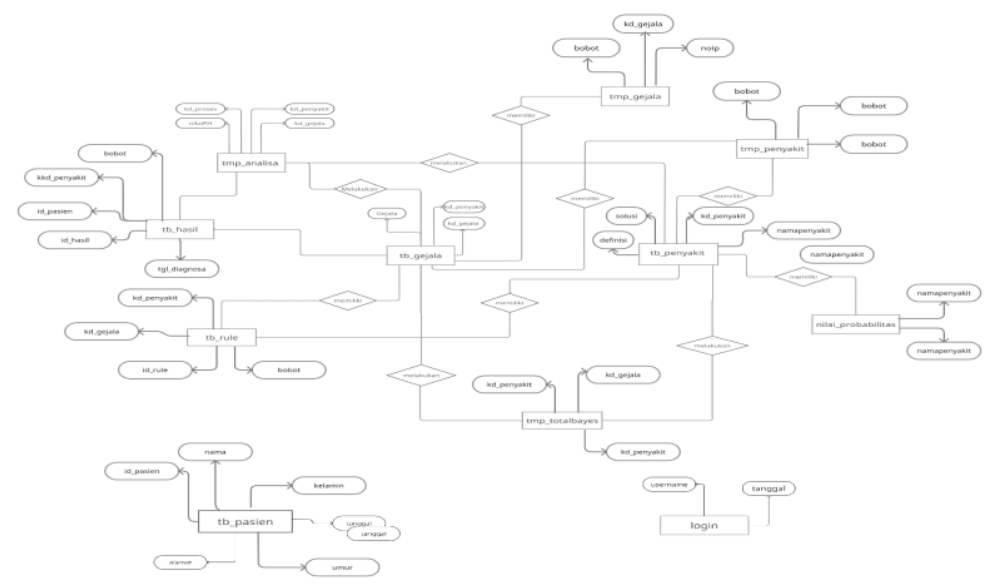

Gambar 3. ERD

Halaman diagnosa pasien

Pada halaman ini sebelum pasien melakukan diagnosa, pasien harus melkakukan registrasi pengguna.

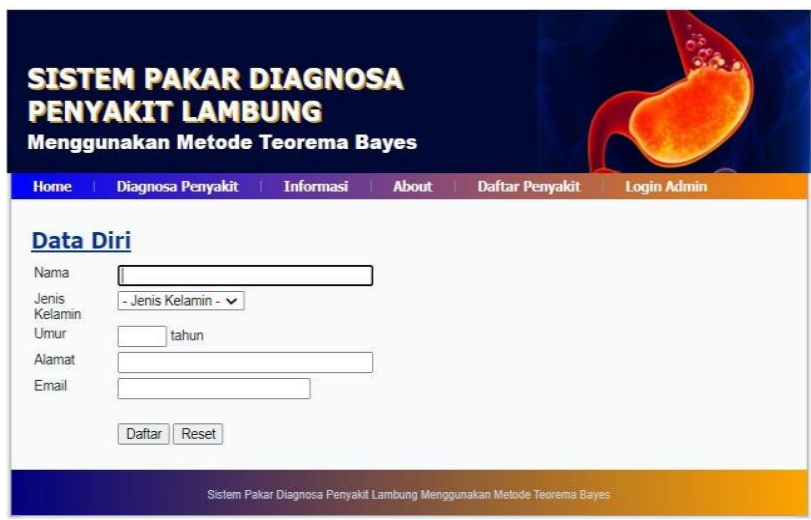

Halaman form diagnosa

Gambar 4. Halaman Diagnosa Pasien

Pada halaman ini pasien melakukan pemilihan gejala berdasarkan gejala yang dialami oleh pasien.

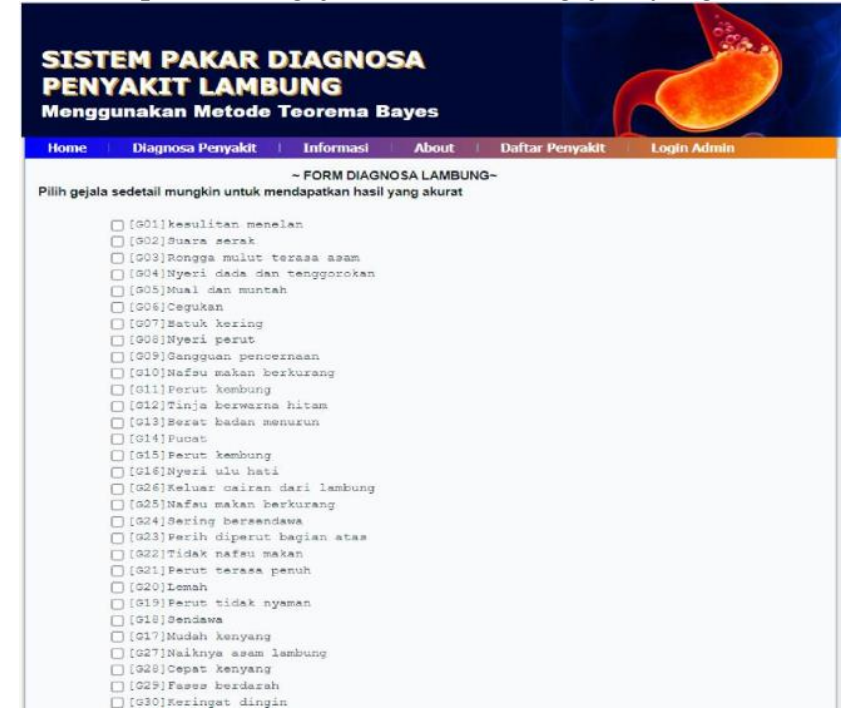

Gambar 5. Halaman Form Diagnosa

Halaman hasil diagnosa 
Procedia of Engineering and Life Science Vol. 1. No. 2 Juni 2021

Seminar Nasional \& Call Paper Fakultas Sains dan Teknologi (SENASAINS 2nd)

Universitas Muhammadiyah Sidoarjo

Pada halaman ini pasien dapat melihat hasil diagnosa yang telah dilakukan pasien berdasarkan gejala yang telah diinputkan sebelumnya.

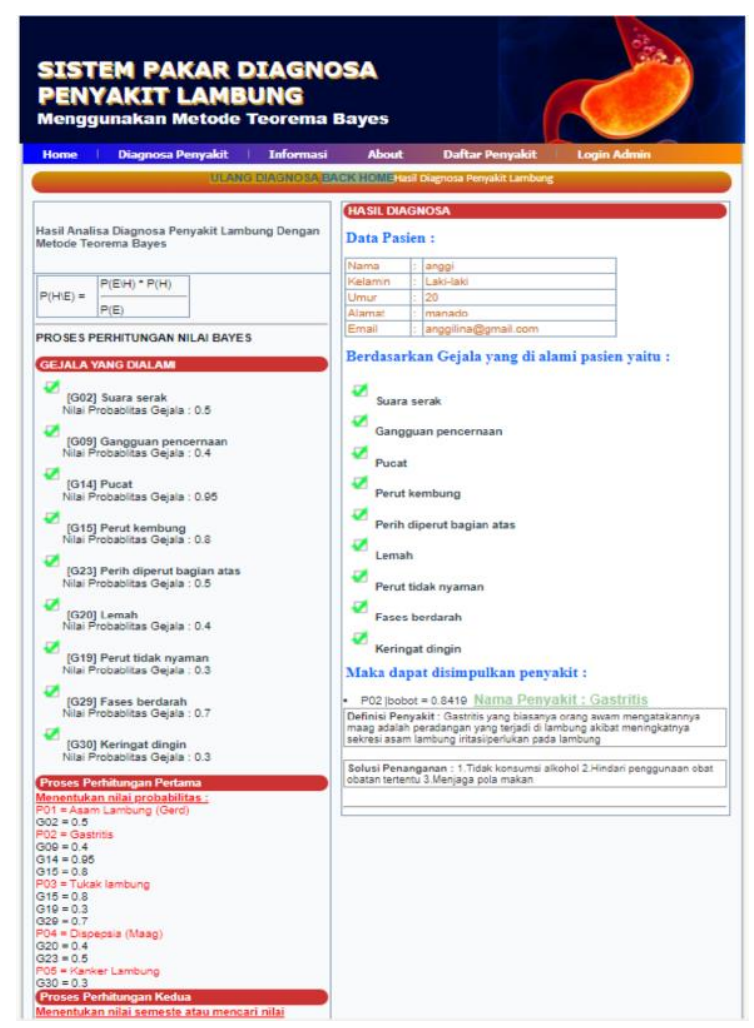

Gambar 6. Halaman Hasil Diagnosa

\section{KESIMPULAN}

Perancangan dan pembangunan sistem pakar dapat mempermudah dalam memberikan informasi bagi pengguna yang terkena penyakit lambung berdasarkan fakta-fakta yang diberikan, selain itu sistem pakar dapat memberikan solusi berdasarkan gejala yang dialami, sehinggan dalam hal ini dapat menjadi acuan bagi pengguna untuk melakukan konsultasi lebih lanjut ke dokter.

\section{UCAPAN TERIMA KASIH}

Dengan penelitian ini, penulis mengucapkan terimakasih banyak kepada semua pihak terkait yang sudah memb antu dalam melakukan penulisan artikel ilmiah yang berjudul "Sistem Pakar Diagnosa Penyakit Lambung Menggunakan Metode Teorema Bayes".

\section{REFERENSI}

[1] M. S. Rika Yunita, "Jurnal Informatika Kaputama(JIK)," SISTEM PAKAR MENDIAGNOSA PENYAKIT LAMBUNG METODE DEMPSTER SHAFER, vol. IV, no. 2, pp. 165-166, 2020.

[2] S. W. Faza Akmal, "Jurnal Sarjana Teknik Informatika," SISTEM PAKAR UNTUK MENDIAGNOSA PENYAKIT LAMBUNG DENGAN IMPLEMENTASI METODE CBR (CASE-BASED REASONING) BERBASIS $W E B$, vol. II, no. 1, p. 119, 2014.

[3] N. H. B. R. Trio Pamujo Wicaksono, "Jurnal Pengembangan Teknologi Informasi dan Ilmu Komputer," Implementasi Metode Naive Bayes Pada Diagnosis Penyakit Lambung, vol. III, no. 1, p. 228, 2019.

[4] W. A. Muhammad Risa, "JURNAL IT," SISTEM CERDAS DIAGNOSA PENYAKIT LAMBUNG BERBASIS WEB DENGAN MENGGUNAKAN METODE CERTAINTY FACTOR, vol. IX, no. 3, p. 203, 2018. 
[5] R. Rinanda, "JATI (Jurnal Mahasiswa Teknik Informatika)," SISTEM PAKAR UNTUK MENDIAGNOSIS PENYAKIT GASTRITIS (MAAG) MENGGUNAKAN METODE CERTAINTY FACTOR DENGAN MESIN INFERENSI FORWARD CHAINING BERBASIS MOBILE ANDROID, vol. II, no. 2, p. 256, 2018.

[6] A. R. d. M. T. Andi Nurkholis, SISTEM PAKAR PENYAKIT LAMBUNG MENGGUNAKAN METODE FORWARD CHAINING, vol. XIII, no. 1, 2017.

[7] F. R. Sari Murni, "Jutikomp," Penerapan Metode Teorema Bayes Pada Sistem Pakar Untuk Mendiagnosa Penyakit Lambung, vol. I, no. 1, 2018.

[8] A. Y. Andi Hendrawan, "JURNAL MANAJEMEN INFORMATIKA," SISTEM PENJAMIN MUTU INTERNAL (SPMI) (DI AKADEMIK KEBIDANAN RESPATI SUMEDANG), vol. VI, no. 1, p. 6, 2017.

[9] H. R. H. Nataniel Dengen, "Jurnal Informatika Mulawarman," Perancangan Sistem Informasi Terpadu Pemerintah Daerah Kabupaten Paser, vol. IV, no. 1, p. 49, 2009.

[10] G. P. Agus Ramdhani Nugraha, "JURNAL MANAJEMEN INFORMATIKA," SISTEM INFORMASI AKADEMIK SEKOLAH BERBASIS WEB DI SEKOLAH MENENGAH PERTAMA NEGERI 11 TASIKMALAYA, vol. IV, no. 2, p. 6, 2017. 